\title{
The Health Risk Behaviours and Social Connectedness of Adolescents in Immigrant Families: Evidence from Australia
}

\author{
Peter Brandon*
}

\begin{abstract}
Using data from Australia, health behavior outcomes and the social connectedness of adolescents in immigrant families are contrasted with the outcomes of adolescents in non-immigrant families. Findings suggest that first and second generation adolescents are less likely to drink alcohol and lack social support than third generation adolescents, but more likely not to be physically active and not to have membership to a social club or group than third generation adolescents. Second generation adolescents are more likely to smoke than third generation adolescents. Findings suggest that immigrant adolescents appear protected from negative risks, yet at the same time, do not benefit from Australia's cultural traditions for physical activity and social participation. Across generations, however, social participation and physical activity increase. Lastly, as length of time in Australia increases, the protective effect of the immigrant family against some negative risks wanes. Overall, the assimilation process leads adolescents in immigrant families to adopt Australia's prevailing social customs of health and social behaviors.
\end{abstract}

In many countries of immigration, large proportions of children are immigrants or have immigrant parents. In the United States, one in every five children is an immigrant or has immigrant parents (Hernandez and Charney 1998). In Australia, about one in every three children under the age of 14 is an immigrant or has at least

\footnotetext{
* Demography and Sociology Program, Research School for Social Sciences, Australia National University, Australia.
} 
one immigrant parent (DIMA 2000; Khoo et al. 2002). Similarly, high proportions of children under the age of 14 in Canada and New Zealand are immigrants or have at least one immigrant parent (Beiser et al. 1998; Statistics New Zealand 1999). Undoubtedly, the future economic prosperity of these countries, the structure and financing of their social institutions, and the civic participation of their citizenry will depend in part on the health status and adjustment of children in immigrant families. ${ }^{1}$

Although the determinants of health status among children in immigrant families and paths to their successful adjustment to a new country are important topics, studies on either are scarce. Hernandez and Charney (1998) argue that the paucity of research is due in part to population-based surveys and health monitoring systems lacking a "generational perspective" that would permit distinguishing among foreign-born children, native-born children with immigrant parents, and native-born children with native-born parents. The literature available, most of which focuses on children in immigrant families in the United States, suggests that in several important areas, children in immigrant families experience better health and have fewer health risk behaviors than do US-born children in US-born families (Harris, 1998; Hofferth, 1999). However, the American studies also indicate that this relative advantage deteriorates with length of stay in the United States and across generations (Hernandez and Charney 1998).

Since the futures of several nations, like the United States and Australia, depend in part on the positive adjustment of children in immigrant families to their host countries, more studies of the health status and social adjustment of children in immigrant families are required. In Australia and the United States, for example the future supply of labour and the financing of health care for the aged are heavily dependent upon each nation's present generation of immigrant children (McDonald, 2003; Hernandez, 2006). So, there is a need to understand the health risk behaviors and social connectedness of adolescents in immigrant families. The transition from adolescence to early adulthood can be difficult and lead youth to feel socially disconnected and display health risk behaviors, such as, use of alcohol or hard drugs, and early sexual activity (National Research Council 1993, 1999). But, repeating the pattern noted above, evidence from the United States suggest that adolescents in immigrant families are less likely to experience health risk behaviors and have better mental health outcomes than US-born adolescents with US-born parents (Harris 1998). Until now, few national level studies from other countries of immigration could corroborate the US-based findings for adolescents in immigrant families.

This study narrows the cross-national gap in knowledge about the health and social adjustment of adolescents in immigrant families. Using data from Australia, 
this study shows that adolescents in immigrant families living in Australia are less likely compared with adolescents in non-immigrant families to use alcohol or lack social support, though some health risk behaviors increase with length of stay in Australia, as well as across generations. Such findings support previous research theorizing that immigrant status imparts a protective effect on adolescents (Harris 1998; Sorenson and Shen 1996; Canadian Council on Social Development 1999).

\section{BACKGROUND}

Despite Australia's future partly depending on children and adolescents in immigrant families, until this study no national level studies of their health status and social adjustment existed. Australia is not alone in lacking such studies. Most countries of immigration also need national level studies on the health and adjustment of children and youth in immigrant families. In the United States, the initial scarcity of national level studies was due in large part to inadequate measures on nativity or sources of data that failed to identify children in immigrant families (Jensen and Chitose 1994; Portes 1996). Presumably, these sorts of problems and financial concerns also explain why other countries of immigration have lacked national-level studies of children in immigrant families. As few national-level studies exist, most of the valuable information on the health and adjustment of children and youth in immigrant families has come from studies of specific locales or ethnic groups (e.g., Waters 1996; Zhou and Bankson 1996; Perez 1994). Exceptions providing national level information, for example studies by Harris (1998) and Kao and Tienda (1995), are from the United States. This study, among the few outside of the United States, is the first national level study in Australia to examine the health risk behaviors and social adjustment of adolescents in immigrant families.

Until recently only limited scientific data at the national level could depict the adaptation process and health of children and adolescents in immigrant families, despite their expanding numbers across the major countries of immigration (Hernandez 1993; Portes and Zhou 1993). Scientific information is now growing, however, with the publications of studies that detail the physical and mental health of children and youth in immigrant families, show their economic circumstances, and describe their pathways to assimilation (National Research Council 1999a; Harris 1998; Kao and Tienda 1995).

As noted, some of the American studies are reassuring because they suggest that the physical health and academic achievement of children and adolescents in immigrant families are better than or equal to those of US-born children 
with US-born parents (National Research Council 1999a). Further, adolescents in immigrant families in Canada are less likely to smoke and use alcohol than Canadian-born children with Canadian-born parents (Canadian Council on Social Development 1999). Nevertheless, other studies from the United States are troubling because they suggest that some children in immigrant families are more likely than US-born children with US-born parents to lack health insurance (Brown et al. 1999), suffer depression and alienation (Rumbaut 1997; SuarezOrozco and Suarez-Orozco 2001), live in poverty and over-crowded housing (Hernandez and Darke 1999), and use welfare (Brandon 1999; Hofferth 1999). Moreover, the North American studies indicate that the advantages possessed by children in immigrant families appear to diminish over time and across generations (National Research Council 1999a; Suarez-Orozco and Suarez-Orozco 2001; Canadian Council on Social Development 1999).

Undoubtedly, more national-level knowledge on the well-being and adjustment of adolescents in immigrant families in countries of immigration is needed. By studying the health risk behaviors and social connectedness of adolescents in immigrant families in Australia, the literature is broadened and the explanatory power of one of the two leading theories of assimilation, "straight-line assimilation" can be assessed. This particular theory predicts that immigrants become increasingly similar to the native population as they spend more time in the country-- basically coming to "blend" into the melting pot (Lieberson, 1970, 1981; Gordon, 1964; Labov, 1967; Lopez, 1996).

Unfortunately, Australian surveys that include immigrants have not progressed sufficiently to explore the other leading theory of assimilation, i.e., "segmented assimilation." This alternative theory to straight-line assimilation suggests that there are multiple pathways of incorporation into a country. The path taken and the conditions associated with it affect the experiences of immigrants and mould their particular assimilation, which may be dissimilar to the prevailing characteristics of the native population (Portes and Zhou, 1993; Rumbaut, 1997; Buriel and De Ment,1997; Waters, 1997). Yet without data on ethnicities within all immigrant generations, especially for the third generation, testing this contrasting theory, which contains a prediction that immigrant youth are at risk of assimilating into the downward status of their non-immigration (third generation) ethnic minority counterparts, is not possible. Although the two theories of immigrant assimilation are quite different, both still share the aim of explaining differences or similarities in the mobility of immigrants (Booth, Crouter, and Landale, 1997).

Studying whether adolescents in immigrant families in Australia are at more or less risk of health risk behaviors and social disconnectedness than adolescents 
in non-immigrant families remains vital. This study examines three health risk behaviors: alcohol use, smoking, and moderate to intensive physical activity. All three have implications for the health and well-being of adolescents. Smoking tobacco is a major contributor to many diseases and imposes enormous costs on societies (AIHW, 1998; WHO, 1998: viii, 2; Collins and Lapsley, 1996). Also, alcohol use is associated with higher mortality and morbidity, and associated with motor vehicle accidents, depression, and crime (AIHW 1998; Moon et al. 1999). Lastly, the health benefits of physical activity are well known and documented (AIHW 1998; Moon et al. 1999).

Social connectedness can affect the health and well-being of adolescents (King et al. 1996; Glover et al. 1998; Resnick et al. 1997). This includes interaction with family and friends and individuals in groups or associations. Despite the importance of social connectedness to the health and well-being of adolescents, few countries have data measuring social connectedness. Yet, feelings of having a family and community to turn to in times of distress have been shown to be beneficial to the health and well-being of young people (Moon et al. 1999). Resnick et al. (1997) studied the effect of "connectedness" on a range of health risk measures among school students in the United States and found a strong protective effect from both family connectedness and school connectedness on nearly every risk behavior measure examined. Connectedness had a strong protective effect against emotional distress, suicidal tendencies, and violence, as well.

\section{HYPOTHESES}

The aim of this study is to better understand the role that immigration plays in explaining variations in the health risk behaviors and social connectedness of adolescents. Although the study recognizes that family structure, parenting style, education level, religiosity, and environment help determine health risk behaviors and mental health among adolescents (Harris, 1998; McLanahan and Sandefur, 1994), the focus here is testing four hypotheses related to immigration.

The first of the hypotheses is that adolescents in immigrant families will be less likely to belong to a club or association compared with adolescents in nonimmigrant families because cultural background and non-English language make the Australian custom of club membership foreign and less attractive. Theoretically, the Australian tradition of building friendships through club membership (Hughes, 2000; Mosler, 2002; Melleuish, 1998) may conflict with immigrant adolescents' loyalties to family. Zhou (1997) has noted that substituting family relationships with peer friendships is often an unfamiliar process for adolescents in immigrant families. 
Second, based on research showing the protective effect of growing up in an immigrant family on adolescents' physical and emotional well-being (Earls 1993; Earls, Escobar, and Manson 1990; Harris 1998), this study also hypothesizes that adolescents in immigrant families are less likely to lack social support. Having more social support in immigrant families relates to immigrant parents' style of parenting, which has been characterized as attentive and protective (Earls 1993; Earls, Escobar, and Manson 1990; Harris 1998). Certainly it makes sense that adolescents in immigrant families should report more social support given that the National Research Council states that attentive parents who listen provide "powerful protection against the possibility that [adolescents] may engage in unhealthy practices, become isolated, or become troubled or depressed" (National Research Council 1999a: 7). Still, according to straight-line assimilation theory, if the protective effect of the immigrant family wanes as length of residency increases, then immigrant youth should be more likely to report a lack of social support.

The third hypothesis is based on the theoretical position that attentive immigrant parents (Slee, 2002; Howes and Aikins, 2002) and culturally-attuned adolescent children in immigrant families should be more likely to have peers with similar backgrounds. This process should lead adolescents in immigrant families to have fewer friends ascribing to Australia's recreational drinking and sport cultures (Mosler, 2002; Waterhouse, 1995; Molony, 1987; Hughes, 1987). Empirically, the combined effect of close family ties and like-minded peers should predict lower alcohol use and physical activity among adolescents in immigrant families compared with their non-immigrant counterparts. As smoking is also a part of the mainstream adolescent culture, adolescents in immigrant families should also be less likely to smoke. This theoretical position is consistent with the literature indicating that immigrant status protects youth in immigrant families from the predominant social norms influencing risky health and lifestyle behaviors (Hernandez and Charney, 1998; Earls, Escobar, and Manson, 1990; BautistaHayes, 1990; Harris, 1998).

Many studies confirm that as immigrants become more integrated into mainstream society, they are more likely to adapt to the lifestyles and habits of the mainstream, including health-related habits. Hence, the fourth hypothesis is that levels of alcohol use and physical activity and odds of smoking should increase with the length of time in Australia and across generations. Already, Earls (1993) and Harris (1998) have confirmed this assimilation phenomenon and Mendoza and colleagues (1990) showed that disease patterns of immigrants shift toward the disease patterns of the majority group. As Hernandez and Charney (1998) note, "immigrant children and youth appear to be protected from negative risks, but 
this advantage tends to decline with length of time in [the United States] and from one generation to the next." (7).

As noted, since other studies have already identified other determinants of health risk behaviors and social connectedness among adolescents, this study refrains from reiterating them. Instead, this study explores the role that immigration plays in explaining variations in the health risk behaviors and social connectedness among adolescents.

\section{DATA}

Data are from the first wave of the Household, Income and Labour Dynamics in Australia (HILDA) Survey, which was collected in 2001. The HILDA survey selected a large nationally representative sample of 7,682 Australian households, thereby yielding a total household response rate of 66 per cent. ${ }^{2}$ Within the 7,682 sampled households, 19,917 persons were enumerated. Interviews were sought with every member of these households who was over the age of 15 years (Watson and Wooden 2002). Of the 19,917 persons, 4,790 were under 15 years of age and ineligible for an interview in Wave 1. This left 15,127 persons eligible for a personal interview 13,969 of which completed the Person Questionnaire and then sought interviews with every member of those households who were over the age of 15 years (Watson and Wooden 2002). The sample of adolescents between the ages of 15 and 19 years numbered 1,244 . Of that adolescent sample, information on generational status was available for 1,217 or 97.8 per cent.

All persons interviewed received a self-completion questionnaire that covered a range of topics, like, lifestyle and health habits, neighbourhood quality, social participation, and social support. Ninety-four per cent, $(\mathrm{N}=13,159)$, of those who had personal interviews completed a self-completion questionnaire. Overall, the HILDA survey collected a rich amount of socio-demographic and economic data on persons aged 15 years and over, including, but not limited to, information on their nativity and immigrant status, ${ }^{3}$ labour force participation, sources of income, family composition, lifestyles, and social participation.

Measuring health risk behaviors, social connectedness, and generational status In the self-completion questionnaire, questions about lifestyle, social participation, and social support are asked of all persons 15 years old and older. Of the adolescent sample, at least 92.2 per cent, $(\mathrm{N}=1,122)$, answered the lifestyle questions and at least 91.7 per cent, $(\mathrm{N}=1,116)$, answered the social participation and social support questions. ${ }^{4}$ 
Three of the lifestyle questions are used to measure the three health risk behaviors: smoking, alcohol use, and moderate to intensive physical activity for at least 30 minutes. The adolescent was asked to indicate the frequencies of alcohol consumption and of moderate to intensive physical activity and whether he or she was a tobacco smoker. Questions from the social participation and social support modules were used to create two measures indicating the connectedness of an adolescent to his or her social context. The first measure indicates whether the adolescent reported he or she was an "active member of a club or association." To develop the second measure of social connectedness, cluster analysis ${ }^{5}$ identified a group of adolescents $(\mathrm{N}=189)$ who "strongly agreed" to four questions about social support; they strongly agreed that they: "often [needed] help from other people, but can't get it", did not "have anyone to confide in", had "no one to lean on in times of trouble", and "often [felt] very lonely." This study reasons that the adolescents strongly agreeing with the four questions lack a social support network and are socially disconnected. Hence, no ties to a social club or association and reports of feeling very lonely and having no one to trust or turn to in times of trouble are considered reliable measures of social disconnectedness among adolescents.

Objective measures of an adolescent's health risk behaviors and social connectedness would have been preferable, but most surveys have to rely on selfreports. Reassuringly, questions from the HILDA self-completion questionnaire have been extensively field-tested and repeatedly used. The alcohol consumption item is based on a question used by the Australian Institute of Health and Welfare for its continuous national household surveys of drug use (AIHW 1999). Likewise, the degree of physical activity question comes from a question in the Australian 1995 National Health and Attrition Survey ${ }^{6}$ (ABS 1996). And, questions on social support have been used in surveys by Henderson et al. (1978) and Marshall and Barnett (1993).

Personal interviews were used to collect the data on country of birth, year of arrival in Australia if not the country of birth, and length of residence since arrival for persons 15 years old or older, and household composition. The data gathered allowed categorizing adolescents from a generational perspective according to the National Research Council's guidelines (1999a). Thus, an adolescent was classified as either foreign-born with foreign-born parents, native-born with at least one foreign-born parent, or native-born with native-born parents. Hernandez and Charney (1998), Brandon (2002), Harris (1998), Hofferth (1999), and Landale, et al. (1998) show that grouping persons according to these definitions captures whether they belong to the first-, second-, or third-generation. Since country of birth was recorded, I could also classify first- and second-generation adolescents by the regions from which they emigrated (ABS 2001). However, 
small sample sizes prevented analyses by country of origin for the alternative generations. (Thus, although the data is limited in this respect, this paper is an advance and adds to the literature. See Appendix A for information on the main countries of origin and changes in those countries of origin over time.) And regrettably, wave one did not collect data that permit distinguishing the country of birth of third-generation adolescents' grandparents. That data unavailability prevents analyses of ethnicity within generations and broadening the study to include the theory of segmented assimilation.

The generational status variables yield proportions for each generational group that are similar to proportions reported by the Australian Bureau of Statistics (ABS 2001). In the HILDA sample, the proportion of first-generation adolescents (14.4 $\%)$ in 2001 is slightly higher than the proportion of first-generation adolescents $(13.7 \%)$ reported by the ABS (ABS 2001). For second-generation adolescents, though, the HILDA proportion (27.8\%) in 2001 basically equals the most recent ABS proportion (28.1\%). Incidentally, either set of statistics shows that over 41 per cent of Australian adolescents are in immigrant families and were increasingly more likely to come from geographically closer countries in the Asian-Pacific region than from the traditional sending countries far away in northern Europe (Khoo, et al., 2002; Khoo, 2003).

\section{METHODS OF ANALYSIS}

Ordered logistic and binary logistic regression models are used to estimate the effects of immigrant generation on measures of health risk behaviors and social connectedness among adolescents. These statistical methods were chosen because the dependent variables are either ordinally scaled or categorical in nature (Agresti, 1990; Long, 1997). From the frequency of alcohol consumption question a fourcategory dependent variable is formed: $1=$ never drink; $2=$ very rarely drink; 3 $=$ drink, but not on a weekly basis; and $4=$ drink regularly, at least on a weekly basis or more. Similarly, the frequency of moderate to intensive physical activity question yields a four-category dependent variable: $1=$ no physical activity at all; $2=$ very rarely physical activity; $3=$ occasional physical activity; and, $4=$ regular physical activity. Questions on smoking, active club or association membership, and no social support produce dichotomous variables coded: $1=$ smoke versus $0=$ do not smoke; $1=$ active club or association membership versus $0=$ not so; and $1=$ no social support versus $0=$ social support. Interpreting the signs of the estimated regression coefficients in the ordered and binary logistic regressions depend upon the nature and rank ordering of the dependent variables. For example, in the alcohol consumption equation a positive regression coefficient means that an increase in the value of an explanatory variable will raise an adolescent's 
( $\log$ ) odds of using alcohol. ${ }^{8}$ The ordered logit for any dependent variable with $J$ ordered categories is defined as:

(1) $Y_{j}=\log \frac{P_{1}+\ldots+P_{j}}{P_{j+1}+\ldots+P_{j}}$,

where $j=1, \ldots, J-1$, and $P_{j}$ is the probability of being in category $j$ of the dependent variable (Long 1997).

\section{RESULTS}

Table 1 shows health risk behaviors and social connectedness for Australian adolescents by immigrant generation. Findings for alcohol consumption are suggestive of an assimilation process across immigrant generations. Foreign-born adolescents with foreign-born parents and native-born adolescents with at least one foreign-born parent compared with native-born adolescents with native-born parents are more likely to never drink alcohol. When first- and second-generation adolescents drink alcohol, the odds are much greater that they drink very rarely compared to third-generation adolescents. Alcohol consumption among nativeborn adolescents with at least one foreign-born parent is higher than foreignborn adolescents with foreign-born parents, (with an exception - the very rarely category), but is lower than native-born adolescents with native-born parents. The difference in alcohol consumption between the two groups of adolescents in immigrant families appears to reflect the assimilation process into Australian society. Whereas the first generation arrive in Australia from their country of origin with varied norms about drinking alcohol, second-generation adolescents grow up in Australia exposed to a prevailing culture of drinking as well as the adolescent culture of experimenting with alcohol. Multivariate analyses show that although the second generation grows up exposed to the Australian drinking culture, immigrant status protects them from drinking alcohol at the same levels as native-born adolescents with native-born parents.

Despite Australian society's penchant for sports and the outdoors ${ }^{9}$, foreign-born adolescents with foreign-born parents and the native-born with at least one foreign-born parent are less likely than native-born adolescents with nativeborn parents to engage in moderate to intensive physical activity. Native-born adolescents with at least one foreign-born parent are more likely to be physically active than foreign-born adolescents with foreign-born parents. The difference in physical activity levels between the two groups of adolescents in immigrant families again reflects assimilation into Australian society. Although future data is required to verify the assertion, most first generation adolescents who come to Australia today most likely include many countries that do not share the same 
fervor for playing sports and pursuing club or recreational pastimes; by contrast, second-generation adolescents, starting in school, learn about Australia's strong sporting traditions, its sports heroes, and where to join a sports club or outdoors organization.

Linear patterns of the cross-tabular findings for alcohol use and physical activity are consistent with the theoretical predictions of straight-line assimilation. Yet, findings in Table 1 for smoking fail to support the theory. Although foreign-born adolescents with foreign-born parents are less likely to smoke than native-born adolescents with native-born parents, native-born adolescents with at least one foreign-born parent are more likely to smoke than native-born adolescents with native-born parents. This disquieting finding, discussed in the conclusion, contradicts several past studies of health risk behaviors among adolescents (National Research Council 1999a).

\begin{tabular}{|c|c|c|c|c|}
\hline & $\begin{array}{c}\text { First } \\
\text { Generation }\end{array}$ & $\begin{array}{c}\text { Second } \\
\text { Generation }\end{array}$ & $\begin{array}{c}\text { Third } \\
\text { Generation }\end{array}$ & Total \\
\hline \multicolumn{5}{|l|}{ Health risk behaviors } \\
\hline \multicolumn{5}{|l|}{ Alcohol consumption ${ }^{\dagger}$} \\
\hline Never drink $\%$ & 38.2 & 22.7 & 20.1 & 23.3 \\
\hline Very rarely drink $\%$ & 32.1 & 41.1 & 32.9 & 35.0 \\
\hline $\begin{array}{l}\text { Drink, but not on a weekly } \\
\text { basis } \%\end{array}$ & 12.8 & 13.2 & 18.9 & 16.5 \\
\hline Drink regularly, at least on a & 16.7 & 23.0 & 28.0 & 25.1 \\
\hline $\mathrm{N}=$ & 129 & 293 & 702 & 1,124 \\
\hline \multicolumn{5}{|l|}{ Physical activity ${ }^{\dagger \dagger}$} \\
\hline No physical activity at all\% & 14.0 & 5.4 & 4.7 & 6.1 \\
\hline Very rarely physical activity\% & 20.0 & 12.9 & 10.7 & 12.6 \\
\hline Occasional physical activity\% & 44.6 & 41.7 & 40.4 & 41.3 \\
\hline Regularly physical activity\% & 21.3 & 39.9 & 44.3 & 39.9 \\
\hline $\mathrm{N}=$ & 129 & 295 & 701 & 1,125 \\
\hline Smoke tobacco\% & 14.3 & 23.5 & 19.1 & 19.6 \\
\hline $\mathrm{N}=$ & 129 & 292 & 701 & 1,122 \\
\hline \multicolumn{5}{|l|}{ Social connectedness measures } \\
\hline No social support $\%$ & 16.4 & 16.0 & 18.2 & 17.3 \\
\hline $\mathrm{N}=$ & 129 & 290 & 697 & 1,116 \\
\hline Active club or association & 37.2 & 46.1 & 54.1 & 49.6 \\
\hline $\begin{array}{l}\text { membership } \% \\
\mathrm{~N}=\end{array}$ & 129 & 290 & 699 & 1,118 \\
\hline \multicolumn{5}{|c|}{ 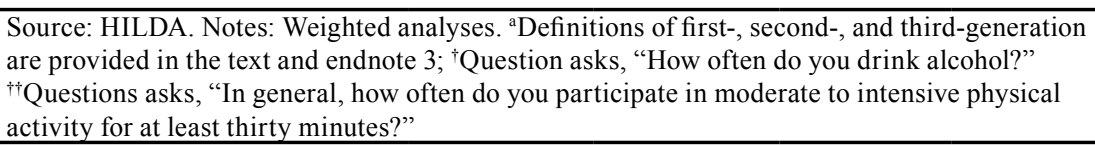 } \\
\hline
\end{tabular}


Reflecting a strong tradition in Australia to actively participate in social life (Evans and Kelley 2002), Table 1 shows that native-born adolescents with either a foreign-born parent or two native-born parents are more likely to be active members of clubs or associations than foreign-born adolescents with foreignborn parents. The low rate of club or association membership among foreignborn adolescents with foreign-born parents is consistent with the theoretical predictions that language barriers and cultural preferences lead foreign-born adolescents with foreign-born parents to find other social outlets, despite the custom of joining clubs, associations, or voluntary organizations. Thus, if club or association membership is a pathway for adolescents in immigrant families to connect with mainstream Australia, foreign-born adolescents with foreign-born parents, especially, are less likely than native-born adolescents with at least one foreign-born parent to use it.

By contrast, immigrant adolescents and native-born adolescents with at least one foreign-born parent appear less likely than native-born adolescents with native-born parents to report no social support. Assimilation theory would argue that first and second generation adolescents feel more social support because of stronger family ties and greater family cohesion. Adolescence is a time when individuals can feel that nobody is there for them, but immigrant status protects first and second generations compared with the third generation from lacking social support.

The comparisons of health risk behaviors and social connectedness in Table 1 provide some insights into the assimilation process for adolescents in immigrant families. However, they are misleading without introducing controls for socioeconomic and demographic differences across the generations. To resolve the concern, multivariate models were employed: dependent variables distinguishing levels of alcohol use and physical activity, and identifying smoking versus not, lacking social support versus not, and active club or association membership versus not were regressed on generational status and other key socioeconomic and demographic control variables.

Table 2 presents descriptive statistics for the control variables used in the multivariate analyses by generational status. The three groups of adolescents are about the same age, but clearly foreign-born adolescents have lived in Australia for a shorter period of time. Roughly, 61 per cent of foreign-born adolescents live in households in which English is not the language spoken by anybody in the household. Fewer adolescents in immigrant families compared with native-born adolescents with native-born parents are likely to have not completed secondary school. Compared to subsequent generations, first-generation adolescents are more likely to state that religion was very important to them. The average size of 
households of first-generation adolescents is slightly smaller than the average sizes of households of second- and third-generation adolescents. ${ }^{10}$ Though as likely to study full-time as second- and third-generation adolescents, first-generation adolescents not enrolled in full-time study are more likely to be unemployed or out of the labour force than the second- and third-generations. Predictably, the first generation's average earnings for the last year were lower than those of the second and third generations.

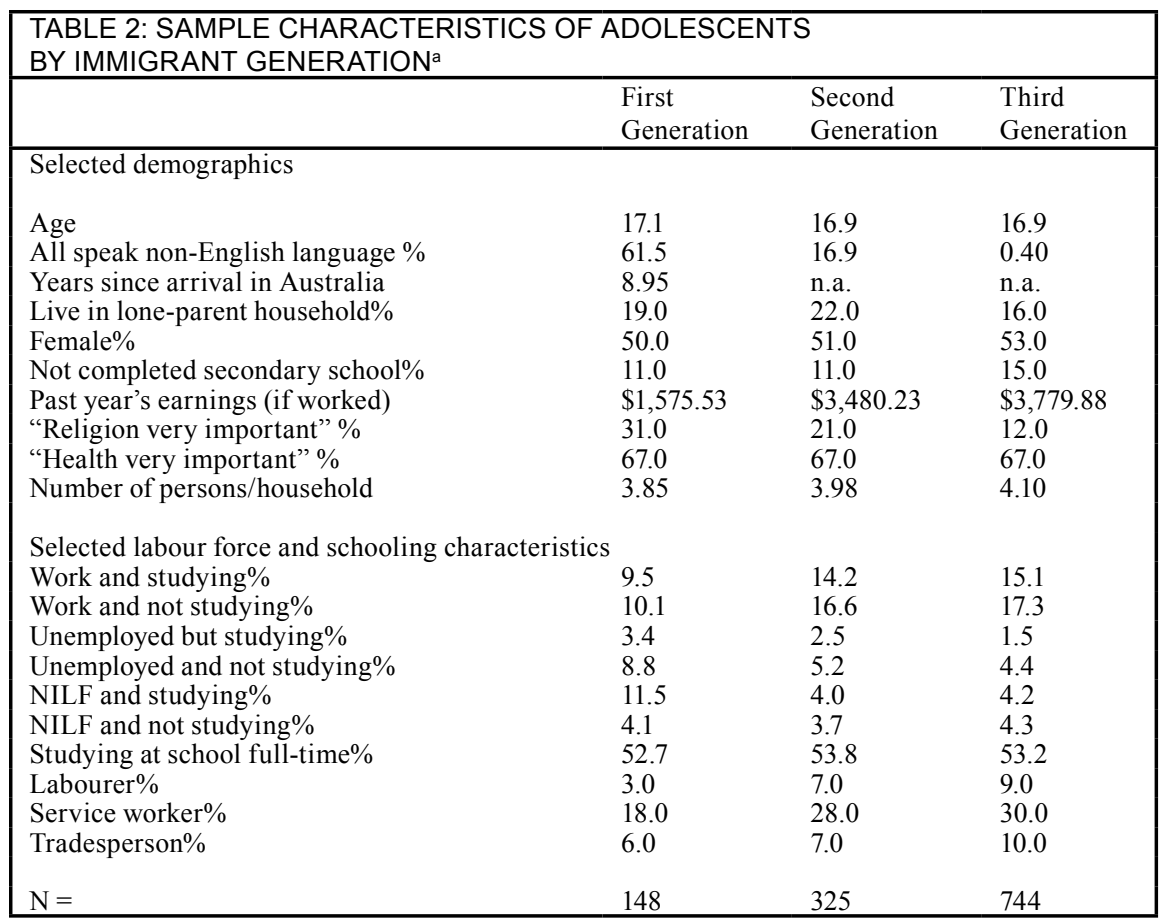

Table 3 shows results from multivariate regression models estimating the likelihood of health risk behaviors among adolescents. Controlling for socioeconomic and demographic factors and attitudes about religion and health, the ordered-logit regression for alcohol use suggests that foreign-born adolescents with foreign-born parents and native-born adolescents with at least one foreignborn parent have lower odds of drinking alcohol than native-born adolescents with native-born parents. ${ }^{11}$ For the first generation, the odds of being in any of the drinking categories are $\exp \{-.914\}=.40$, or less than half those of nativeborn adolescents with native-born parents (the omitted category). For the second generation, the odds of being in any of the drinking categories are exp $\{-.220\}$ $=.80$, or 80 per cent of native-born adolescents with native-born parents. With control variables added, native-born adolescents with at least one foreign-born 
parent are only marginally less likely to drink alcohol than native-born adolescents with native-born parents. The smaller difference in alcohol use between the two groups of native-born adolescents is possible not surprising given both groups have greater exposure to Australian culture. Even though one group has at least one immigrant parent, both groups grow up with Australian norms about drinking and so immigrant status should have less of a protective effect relative to the first generation.

Second, though the mix of immigrants to Australia is changing (see Appendix A), the second generation's parents were more likely than the first generation's parents to have emigrated from European countries like the United Kingdom and Ireland, which have similar norms about drinking alcohol as those of Australia. Language and duration of time since arrival also significantly change the odds of alcohol use. If everyone in the household of the adolescent speaks another language other than English, they are less than half as likely $\exp \{-.83\}=0.43$ as adolescents living in households in which one or more household members speak English to drink alcohol. Further, the longer the length of time spent in Australia, the more likely are foreign-born adolescents with foreign-born parents to drink alcohol.

\begin{tabular}{|c|c|c|c|c|c|c|}
\hline \multirow{3}{*}{ Health Risk Behavior } & \multicolumn{4}{|c|}{ Ordered-Logit Regressions } & \multirow{2}{*}{\multicolumn{2}{|c|}{$\begin{array}{c}\text { Logit Regression } \\
\text { Smoke tobacco }\end{array}$}} \\
\hline & \multicolumn{2}{|c|}{$\begin{array}{l}\text { Level of Alcohol } \\
\text { Use }\end{array}$} & \multicolumn{2}{|c|}{$\begin{array}{c}\text { Level of Physical } \\
\text { Activity }\end{array}$} & & \\
\hline & Coefficient & S.E. & Coefficient & S.E. & Coefficient & S.E. \\
\hline \multicolumn{7}{|l|}{ Independent Variables } \\
\hline First generation ${ }^{\mathrm{a}}$ & $-0.914 * *$ & 0.3907 & $-1.1327 * * *$ & 0.3826 & 0.2429 & 0.6139 \\
\hline Second generation $^{\mathrm{a}}$ & $-0.2201 *$ & 0.1376 & 0.0525 & 0.1407 & $0.5014 * * *$ & 0.1920 \\
\hline $\begin{array}{l}\text { All speak non-Enlgish } \\
\text { language }\end{array}$ & $-0.8332 * * *$ & 0.2354 & $-0.4981 * *$ & 0.2284 & $-0.7305^{* *}$ & 0.3857 \\
\hline $\begin{array}{l}\text { Years since arrival in } \\
\text { Australia }\end{array}$ & $0.0779 * * *$ & 0.0326 & $0.0653 * *$ & 0.0322 & 0.0001 & 0.0499 \\
\hline Live in lone-parent household & 0.0401 & 0.1527 & -0.0639 & 0.1549 & $0.4133 * *$ & 0.2101 \\
\hline Number of persons/household & $-0.094 * *$ & 0.0433 & 0.0286 & 0.0435 & -0.0684 & 0.0642 \\
\hline Past year's earnings $(\log )$ & 0.0253 & 0.0163 & 0.00936 & 0.0168 & -0.0247 & 0.0233 \\
\hline Live in inner regional & -0.278 & 0.5633 & -0.0124 & 0.1371 & -0.7067 & 0.6859 \\
\hline Live in outer regional & -0.3313 & 0.5672 & $0.3786^{* *}$ & 0.1826 & -0.9476 & 0.6963 \\
\hline Live in remote area & -0.2076 & 0.5768 & $1.5556^{* *}$ & 0.6687 & -0.416 & 0.7072 \\
\hline Age & $0.4238^{* * *}$ & 0.0633 & -0.0705 & 0.0636 & 0.1811 & 0.0912 \\
\hline Female & $-0.2276^{* *}$ & 0.1193 & $-0.6708^{* *}$ & 0.1225 & -0.0101 & 0.1804 \\
\hline
\end{tabular}




\begin{tabular}{|c|c|c|c|c|c|c|}
\hline \multirow{3}{*}{ Health Risk Behavior } & \multicolumn{4}{|c|}{ Ordered-Logit Regressions } & \multirow{2}{*}{\multicolumn{2}{|c|}{$\begin{array}{l}\text { Logit Regression } \\
\text { Smoke tobacco }\end{array}$}} \\
\hline & \multicolumn{2}{|c|}{$\begin{array}{c}\text { Level of Alcohol } \\
\text { Use }\end{array}$} & \multicolumn{2}{|c|}{$\begin{array}{c}\text { Level of Physical } \\
\text { Activity }\end{array}$} & & \\
\hline & Coefficient & S.E. & Coefficient & S.E. & Coefficient & S.E. \\
\hline \multicolumn{7}{|l|}{ Independent Variables } \\
\hline $\begin{array}{l}\text { Not completed secondary } \\
\text { school }\end{array}$ & $-0.3438 *$ & 0.2035 & 0.3082 & 0.2063 & $0.4389 * *$ & 0.2470 \\
\hline Work and studying & $0.7177 * * *$ & 0.2438 & -0.1125 & 0.2485 & $0.621^{*}$ & 0.351 \\
\hline Work and not studying & $0.4976^{* *}$ & 0.2389 & -0.2443 & 0.2444 & $0.7917 * *$ & 0.3408 \\
\hline Unemployed but studying & $1.1096^{* * *}$ & 0.4588 & 0.3111 & 0.4634 & 0.8692 & 0.5512 \\
\hline Unemployed but not studying & $0.5292 *$ & 0.3288 & -0.1578 & 0.3365 & $1.4979^{* * *}$ & 0.421 \\
\hline NILF and studying & 0.2001 & 0.3013 & -0.2761 & 0.3056 & -0.4361 & 0.5044 \\
\hline NILF and not studying & $0.7502 * *$ & 0.3756 & -0.2823 & 0.3787 & $1.39 * * *$ & 0.4717 \\
\hline "Religion very important" & $-0.7543 * * *$ & 0.1589 & $-0.2756^{*}$ & 0.1575 & $-0.9342 * * *$ & 0.2923 \\
\hline "Health very important" & $-0.2559 * *$ & 0.1208 & $0.4122 * * *$ & 0.1226 & $-0.5588 * * *$ & 0.1727 \\
\hline Tradesperson & $0.6361 * * *$ & 0.2657 & -0.00116 & 0.2683 & 0.2238 & 0.3671 \\
\hline Service worker & 0.2418 & 0.162 & -0.1583 & 0.1653 & 0.0188 & 0.2532 \\
\hline Laborer & $0.4699 * *$ & 0.2259 & 0.2731 & 0.2373 & -0.4347 & 0.3192 \\
\hline Cutpoint 1 & $-7.843 * * *$ & 1.117 & 0.4514 & 1.105 & $-1.17 * * b$ & 1.725 \\
\hline Cutpoint 2 & $-6.878 * * *$ & 1.117 & $2.489 * * *$ & 1.0188 & & \\
\hline Cutpoint 3 & $-4.960 * * *$ & 1.116 & $3.8392 * * *$ & 1.0246 & & \\
\hline Log-likelihood & $-1,340.32$ & & $-1,226.63$ & & -472.77 & \\
\hline Number of observations & 1,124 & & 1,125 & & 1,122 & \\
\hline $\begin{array}{l}* \mathrm{p}<.10 * * \mathrm{p}<.05 * * * \mathrm{p}<.0 \\
\text { first-, second-, and third-ger } \\
\text { tobacco." }\end{array}$ & -tailed $t$ & Sou & HILDA & 1). $\mathrm{N}$ & Definitic & $\begin{array}{l}\text { of } \\
\text { Smoke }\end{array}$ \\
\hline
\end{tabular}

The regression for frequency of moderate to intensive physical activity for 30 minutes or more shows that foreign-born adolescents with foreign-born parents have lower odds of engaging in such activity compared with nativeborn adolescents with native-born parents. Their odds of being in any physical activity category are $\exp \{-1.19\}=0.32$, or roughly one-third those of native-born adolescents with native-born parents (the omitted category). With control variables added, the odds of native-born adolescents with at least one foreign-born parent being physically active are no different from the odds of native-born adolescents with native-born parents being physically active. The insignificant difference between these two groups implies that after controlling for socio-demographic factors the frequency of physical activity between the two groups is similar, even 
if some adolescents' parents were foreign-born. Duration of time since arrival has an influence on the amount of moderate to intensive physical activity, as well. The longer the length of time since arrival, the more likely foreign-born adolescents with foreign-born parents are to do moderate to intense physical activity for thirty minutes or more. If everyone in the household of the adolescent speaks another language, other than English, they are less likely by about two-thirds exp $\{-.498\}$ $=0.60$ compared with adolescents living in households in which one or more household members speak English to engage in physical activity.

Table 3 shows that after controlling for socio-demographic factors, native-born adolescents with at least one foreign-born parent are still found to have higher odds of smoking compared with native-born adolescents with native-born parents. Their odds of smoking are $\exp \{.50\}=1.65$, or over one and a half times those of native-born adolescents with native-born parents. Reflecting the small difference in Table 1, foreign-born adolescents with foreign-born parents are no more or no less likely to smoke than native-born adolescents with native-born parents. Though duration of time since arriving in Australia has no discernible effect on the odds of smoking, living in a household in which a language other than English is spoken by everyone makes adolescents in those households less than half as likely $\exp \{-.73\}=0.48$ to smoke compared with adolescents in households in which a language other than English is not spoken by everyone.

Table 4 displays results for the two social connectedness measures. Foreign-born adolescents with foreign-born parents are less likely than native-born adolescents with native-born parents to strongly agree that they have no social support. The coefficient for native-born adolescents with at least one foreign-born parent also suggests, (though statistically insignificant), that perhaps they too are less likely than native-born adolescents with native-born parents to report no social support. Of the two, however, first generation adolescents have a little less than one-third the odds of no social support as native-born adolescents with native-born parents. In addition, if everyone in the household of the adolescent speaks a language other than English, they are over two times as likely $\exp \{.785\}=2.18$ as adolescents living in households in which one or more household members speak English to report no social support. This result may reflect a tension second-generation adolescents feel growing up in a household where English is not the language spoken, yet beyond the household English is the means of communication. The longer the length of time since arrival in Australia has no impact on reporting a lack of social support. 


\begin{tabular}{|c|c|c|c|c|}
\hline \multirow{3}{*}{ Social connectedness measures: } & \multicolumn{4}{|c|}{ Logit Regressions } \\
\hline & \multicolumn{2}{|c|}{ No social support } & \multicolumn{2}{|c|}{$\begin{array}{l}\text { Active club/assoc. } \\
\text { membership }\end{array}$} \\
\hline & Coefficient & S.E. & Coefficient & S.E. \\
\hline \multicolumn{5}{|l|}{ Independent Variables } \\
\hline First generation $^{\mathrm{a}}$ & $-1.114 * *$ & 0.560 & -0.1530 & 0.444 \\
\hline Second generation $^{\mathrm{a}}$ & -0.2634 & 0.210 & $-0.2635^{*}$ & 0.154 \\
\hline All speak non-Enlgish language & $0.7832 * * *$ & 0.325 & $-1.0135^{* * *}$ & 0.269 \\
\hline Years since arrival in Australia & 0.0613 & 0.047 & -0.00542 & 0.038 \\
\hline Live in lone-parent household & -0.1887 & 0.215 & -0.1513 & 0.172 \\
\hline Number of persons/household & 0.0166 & 0.062 & 0.0408 & 0.049 \\
\hline Past year's earnings $(\log )$ & 0.00625 & 0.024 & -0.0281 & 0.019 \\
\hline Live in inner regional & 0.8741 & 1.063 & 0.2432 & 0.623 \\
\hline Live in outer regional & 0.9895 & 1.066 & 0.1635 & 0.627 \\
\hline Live in remote area & 1.08 & 1.076 & 0.4895 & 0.639 \\
\hline Age & 0.1198 & 0.089 & -0.0137 & 0.071 \\
\hline Female & -0.2637 & 0.173 & $-0.4670 * * *$ & 0.134 \\
\hline Not completed secondary school & $0.6679 * * *$ & 0.281 & 0.1170 & 0.231 \\
\hline Work and studying & -0.4644 & 0.359 & -0.2803 & 0.273 \\
\hline Work and not studying & -0.1280 & 0.340 & $-0.6617 * *$ & 0.269 \\
\hline Unemployed but studying & -0.6333 & 0.694 & -0.6567 & 0.522 \\
\hline Unemployed but not studying & $-0.9220 *$ & 0.521 & $-0.6790 *$ & 0.377 \\
\hline NILF and studying & -0.3619 & 0.448 & -0.4128 & 0.346 \\
\hline NILF and not studying & -0.0714 & 0.502 & $-1.2233 * * *$ & 0.463 \\
\hline "Religion very important" & 0.3304 & 0.241 & -0.1098 & 0.177 \\
\hline "Health very important" & 0.2021 & 0.171 & -0.1721 & 0.135 \\
\hline Tradesperson & 0.2091 & 0.374 & -0.2590 & 0.293 \\
\hline Service worker & -0.0506 & 0.233 & -0.1945 & 0.181 \\
\hline Laborer & 0.3847 & 0.343 & -0.0956 & 0.254 \\
\hline Constant & $-4.510 * * *$ & 1.899 & 0.9102 & 1.374 \\
\hline Log-likelihood & 493.280 & & 724.950 & \\
\hline Number of observations & 1,116 & & 1,118 & \\
\hline
\end{tabular}

Contrasting the results showing a tendency toward not lacking social support among adolescents in immigrant families are the results indicating that adolescents 
in immigrant families have lower odds of active membership in a social club or association than adolescents in non-immigrant families. This other tendency is consistent with results in Table 1, but only native-born adolescents with at least one foreign-born parent have significantly lower odds of having no active club or association membership compared to native-born adolescents with native-born parents: they have just over three-quarters the odds compared to native-born adolescents with native-born parents, $\exp \{-0.263\}=0.77$. Living in a household where everyone speaks a language other than English has a negative impact on the chances of following the Australian tradition of joining a club or association. If everyone the adolescent lives with speaks another language, other than English, those adolescents have just over one-third of the odds $\exp \{-1.013\}=0.36$ of club or association membership compared with their peers. Again, the longer the length of time since arrival in Australia has no impact on joining a club or association.

Other findings support theories arguing that personal traits and values, family structure, and contextual factors are associated with adolescent health risk behaviors. Adolescents who state that religion and their health are very important in their lives are found less likely to drink alcohol and smoke than those who state otherwise. And, those stating that their health is very important are more likely to engage in moderate to intensive physical activity. Those who failed to complete secondary school are, unexpectedly, less likely to drink alcohol than those still in school or working, but are more likely to smoke and lack social support. Females compared with males were less likely to drink alcohol, engage in physical activity, or have active membership in a club or association. Family structural effects were weak. Living in a lone-parent household compared to not, significantly increases the odds of smoking only, though coefficients in the two tables imply that adolescents in lone-parent households have lower odds than other adolescents of joining a club, having physical activity, and feeling supported, but higher odds of drinking alcohol. Results are comparable to earlier reported ones (see Harris, 1998; McLanahan, 1988; McLanahan and Sandefur, 1994; National Research Council, 1993; Thornton and Camburn, 1987; Evans and Kelley, 2002.)

\section{CONCLUSIONS}

Significant portions of Australia's young people are immigrants or the Australianborn sons and daughters of immigrant parents. These children and adolescents are increasingly likely to come from Asian-Pacific countries close-by rather than from European countries far away. With the exception of New Zealanders, many of these children and youth will have no familiarity with Australia's sports, 
recreational, and social traditions, or its cultural acceptance of alcohol. This study concludes that immigrant status imparts a protective effect on immigrant adolescents with respect to the risks associated with alcohol use and feeling unsupported in times of distress. The findings for alcohol use also lead to the same conclusion of past studies that the relative advantage of growing up in an immigrant family weakens with length of stay and across generations. Rather than across time, findings for social support suggest that across generations the relative advantage of growing up in an immigrant family diminishes.

Finding that second-generation adolescents are more likely to smoke compared with third-generation adolescents is troubling, however. Without evidence, presuming that they experiment more with tobacco products compared with the third generation seems implausible. What is plausible is that smoking results from acculturative stress ${ }^{12}$ (Aronowitz, 1984; Gil et al,. 1994; Gil and Vega, 1996). Over time, the gap between the values and cultural practices of parents of second-generation adolescents and those of their adolescent children may widen causing tension and conflict. Research has shown that adolescents in immigrant families experiencing acculturative stress are more likely than their peers to exhibit psychological distress, such as depression and low self-esteem (Gil et al., 1994; Pawliuk, et al., 1996). Perhaps smoking among second-generation adolescents living in households in which nobody speaks English, could possible be a manifestation of acculturative stress, as well.

While perhaps disquieting to find that immigrant adolescents adapt to the prevailing social norms associated with drinking alcohol, and that subsequent generations to the first are more likely to feel socially unsupported, other evidence is encouraging about immigrant adolescents' adaptations to Australia's healthrelated social norms. As length of time increases and across generations, doing moderate to intensive physical activity for at least thirty minutes increases. Thus, adolescents in immigrant families appear to adopt the Australian tradition of being physically active, which thereby promotes healthy lifestyles.

Overall, the evidence supports the straight-line theory about the assimilation process of immigrant youth. With the exception of smoking and club or association membership for second-generation adolescents, the theme that emerges is that adolescents in immigrant families adopt Australia's behavioral norms regarding health risk behaviors and social participation. Data limitations prevent testing segmented assimilation theory or reconciling different propensities for health risk behaviors by generational status. Certainly, future research in Australia and elsewhere must consider alternative theories and the additional precursors to health risk behaviors. Still, with the caveat that HILDA data are self-reported, as it is a prospective longitudinal study, future opportunities exist to collect 
country of origin data on HILDA respondents and thereby test the segmented assimilation theory.

Future research should also include studies that investigate the family and environmental mechanisms that affect the health risk behaviors and social connectedness of adolescents in immigrant families. While recognizing the protective effect of the immigrant family on adolescents, other Australian institutions, for example, school and neighbourhood, may attenuate or intensify health risk differentials across immigrant generations. Likewise, a raft of new social policies, such as new residency and eligibility requirements for social services and health care (Social Security Portfolio 1997), may differentially affect adolescents in immigrant and non-immigrant families.

The evidence suggests a role for policy interventions. National policies or programmes that encourage immigrant adolescents to engage in physical activities would be beneficial. And, anti-smoking programmes for second-generation adolescents are especially necessary, as well as research on the determinants of their higher rate of smoking. Such targeted programmes could fail, though, if insufficient attention were given to providing non-English speaking programmes. This study shows that some health risk behaviors and social connectedness are associated with non-use of English in immigrant households. Also, the effectiveness of intervention programmes would rise if the ethnicity or country of origin of the adolescent were identified.

Additionally, government programmes could more widely publicize the beneficial aspects of having immigrant families. Most Australians are probably unaware that many adolescents in immigrant families are less, not more, likely to use alcohol, feel unsupported, and leave high school prematurely, and that they come to embrace Australia's social customs rather than reject them. Moreover, since cultural differences and family practices in immigrant families protect adolescents from lacking social support and from alcohol use, government could fund studies that aim to pinpoint the family practices in immigrant families that are potentially helpful for non-immigrant families who must also protect adolescents from alcohol abuse. Odd as it might seem, the key evidence here suggests that government policy strategists may not want to necessarily expend monies stopping immigrant adolescents from drinking more, but rather, invest monies in learning from immigrant families how they help third generation Australians drink less. Ultimately, the policy interventions devised now to reduce health risk behaviors and promote social connectedness among Australia's immigrant (and non-immigrant) adolescents will partly decide Australia's social and economic life in the future. 


\section{ACKNOWLDGEMENTS}

The author wishes to thank members of the Department of Family and Community Services, especially Carole Heyworth for assistance with extracting and processing of data, as well as Siew-Ean Khoo from the Australian National University for help with Australian immigration statistics. The author also thanks colleagues from the National Institutes for Child Health and Development's Family and Child Well-Being Research Network and two anonymous reviewers for helpful suggestions that improved the paper.

\section{NOTES}

1 Since the 1970s, Australia, Canada, the United States and New Zealand have all experienced increased diversity through immigration. However, Australia's levels of immigration on a per capita basis outpace those of these other countries of immigration (Khoo 2003: p. 159).

2 Response rates compare favorably with rates in the first waves of HILDA's British and German counterparts (Wooden, Freidin, and Watson, 2002). Comparisons with population data from the Australian Bureau of Statistics suggest that the sample has characteristics corresponding with what would have been expected in the sample were it truly random. Observable differences between the responding and selected samples are corrected by applying provided population weights.

3 Data collected in Wave 1 on persons aged 15 years and over on country of birth, year of arrival in Australia if Australia was not the country of birth, length of residence since arrival, parental information, as well as data on household composition permitted me to identify adolescents in the HILDA survey from a generational perspective. Thus, I could categorize adolescents as either foreign-born with foreign-born parents (firstgeneration), or native-born with at least one foreign-born parent (second-generation), or native-born with native-born parents (third-generation). As country of birth was recorded, I could categorize them according to established regional categories frequently used by researchers to identify regions from which emigrates came (ABS 2001).

4 Non-response rates for the questions were alike across years of age. Of the 95 adolescents not answering the smoking question, 19, 33, and 43 were first-, second-, and third-generation adolescents, respectively. As shown, sample sizes are slightly variable because adolescent responses to the lifestyle and social participation and support items varied slightly.

5 Cluster analysis is a general term for a wide range of methods used to examine multivariate data aimed at uncovering or discovering groups or clusters of homogeneous observations.

6 In the survey, data was collected about exercise for sport and recreation and health fitness only. Work related physical activity was excluded. The study defined "moderate" as a 'moderate increase in heart rate or breathing' and intense or "vigorous" exercise 
as 'causing perspiration or large increases in heart rate or breathing' (Moon et al. 1999, p. 137).

7 Youth in immigrant families originated from numerous regions. Among first-generation youth, regional origins included: Oceania 10.1per cent, Europe 23.0 per cent, Middle East 8.8 per cent, Asia 40.5 per cent, Americas 3.4 per cent, and Africa 14.2 per cent; for second-generation youth, regional origins included: Oceania 6.2 per cent, Europe 55.7 per cent, Middle East 4.0 per cent, Asia 12.6 per cent, Americas 3.1 per cent, Africa 3.1 per cent, and 15.3 per cent with parents foreign-born, but not providing a region of birth.

8 Another distinctive feature of the ordered logit is interpretation of the threshold parameters or "cutpoints." Exponentiated values of the cutpoints in the regressions presented here form the baseline odds for adolescents belonging to the omitted category (Long 1997). Following the recommendation of Allison (1999, p. 140), explanations of the cutpoints are excluded from the discussion; more is gained by focusing on the groups of interest compared to the omitted category.

9 Though the sports culture of the country of origin is unknown, Australian society is distinctively known for its sports, recreation, and leisure cultures and many argue that this demarcates Australian society from other nations.

10 This finding is surprising as immigrant households are found to have more persons on average than non-immigrant households (Hernandez and Charney 1998; Brandon 2002).

11 The score test for the proportional odds assumption was marginally significant, $(\alpha=$ 0.1098), indicating that the ordered logit may be inappropriate. Yet, as Long (1997) and Allison (1999) cautioned, the test tends to reject the null hypothesis too frequently. This warning and sensitivity tests on the model showing that the $\alpha_{\text {level could became }}$ marginally insignificant, lead to the decision, based on theory and the good quality of these data, to fit the ordered logit regression.

12 Acculturative stress is the psychological tensions that adolescents and their families experience as they acculturate to the values and mores of the host country that may conflict with their own.

\section{REFERENCES}

Agresti, A.

1990. Categorical Data Analysis, New York, John Wiley and Sons, New York. Allison, P.D.

1999 Logistic Regression Using SAS System: Theory and Application. SAS Institute Inc., Cary North Carolina.

Aronowitz, $\mathrm{M}$.

1984. "The social and emotional adjustment of immigrant children: a review of the literature", International Migration Review 18(2): 237-257. 
Australian Bureau of Statistics.

1996 National Health Survey, Users' Guide, 1989-90 and 1995, Catalogue No. 4363.0, ABS, Canberra.

2000a Overseas Arrivals and Departures Cat. No. 3410.0, ABS, Canberra.

2000b Estimated Resident Population by Country of Birth, ABS, Canberra.

2001a Migration: Australia 1999-2000, Catalogue No. 3412.0 ABS, Canberra.

2001b Australian Social Trends, Catalogue No. 4102.0, ABS, Canberra.

Australian Institute for Health and Welfare,

1998 Australia's Health 1998: The Sixth Biennial Health Report of the Australian Institute of Health and Welfare, AIHW Cat. No. AUS 10, AIHW, Canberra.

Australian Institute for Health and Welfare

19991998 National Drug Strategy Household Survey: First Results, AIHW cat no. PHE 15, AIHW Drug Statistics Series, Canberra.

Bautista-Hayes. D.E.

1990. "Latino health indicators and the underclass model: from paradox to new policy methods", Chicano Studies Research Center, UCLA, Los Angeles (unpublished manuscript).

Beiser, M. Hou, F., Hyman, I. And Tousignant.

1998 Growing Up Canadian-A Study of New Immigrant Children, Catalogue No. W-98-24E, Applied Research Branch Human Resources Development, Canada.

Booth, A., A. C. Crouter and N. Landale

1997 Immigration and the Family: Research and Policy on U.S. Immigrants, Lawrence Erlbaum Associates, Inc., Mahway, New Jersey.

Brandon, Peter D.

2002 "The living arrangements of children in immigrant families in the United States: a test of the segmented assimilation hypothesis." International Migration Review 36 (2): 416-436.

Brandon, P. D.

1999 "Public assistance receipt among immigrant children and their families: evidence from the survey of program participation", in D.J. Hernandez (Ed), Children of Immigrants: Health, Adjustment, and Public Assistance, Committee on the Health and Adjustment of Immigrant Children and Families, Board on Children, Youth, and Families, National Academy Press, Washington, DC.

Brown, E. R., et al.

1999 "Access to health insurance and health care for children in immigrant families", in D.J. Hernandez (Ed.), Children of Immigrants: Health, Adjustment, and Public Assistance, Committee on the Health and Adjustment of Immigrant Children and Families, Board on Children, Youth, and Families, National Academy Press, Washington, DC.

Buriel, R. and T. De Ment

1997 "Immigrant and sociocultural change in Mexican, Chinese, and Vietnamese American families", in A. Booth, et al. (Eds.), Immigration and the Family: Research and Policy on U.S. Immigrants, Lawrence Erlbaum Associates, Inc., Mahwah, New Jersey: 150-165. 
Burnley, I.H.

2001 The Impact of Immigration on Australia: A Demographic Approach, Oxford University Press, Melbourne.

Canadian Council on Social Development

1999 Immigrant Youth in Canada. http://www.ccsd.ca.subsites/cd/doc/iy/lifestyl. htm.

Collins, D. and H.M. Lapsley

1996 "The social costs of drug abuse in Australia in 1988 and 1992", National Drug Strategy Monograph Series No. 30, Australian Government Publishing Service.

Department of Immigration and Multicultural Affairs

2000 Community Profiles 1996 Census (various birthplace groups), Canberra.

Earls, F.

1993 "Health promotion for minority adolescents: cultural considerations", in S.G. Millstein, et al. (Eds.), Promoting the Health of Adolescents: New Directions for the Twenty-First Century, Oxford University Press, Oxford: 58-72.

Earls, F. J.I., S.M. Escobar and S.M. Manson

1990 "Suicide in minority groups: epidemiological and cultural perspectives", in S.J. Blumenthal and D.J. Kupfer (Eds.), Suicide over the Life Cycle, American Psychiatric Association Press, Washington, DC: 571-598.

Evans, M.D.R., and J. Kelley

2002 Australian Economy and Society: Education, Work, and Welfare, The Federation Press, Sydney.

Gil, A. G, and W.A. Vega

1996 "Two different worlds: acculturation stress and adaptation among Cuban and Nicaraguan families", Journal of Social and Personal Relationships 13(3): 435-456.

Gil, A. G., W.A. Vega, and J.M Dimas

1994 "Acculturation stress and personal adjustment among Hispanic adolescent boys", Journal of Community Psychology 22: 43-55.

Glover, S., J. Burns, H. Bulter and G. Patton

1998 "Social environments and the emotional wellbeing of young people", Family Matters 49: 11-16.

Gordon, M.

1964 Assimilation in American Life: The Role of Race, Religion, and National Origins, Oxford University Press, New York.

Harris, K.M.

1998 "The health status and risk behavior of adolescents in immigrant families", in D. Hernandez (Ed.), Children of Immigrants: Health, Adjustment, and Public Assistance, Committee on the Health and Adjustment of Immigrant Children and Families, Board of Children, Youth, and Families, National Academy Press, Washington, DC.

Henderson, S., et al.

1978 'The patient's primary group', British Journal of Psychiatry 132: 74-86.

Hernandez, D. J.

1993 America's Children: Resources from Family, Government, and the Economy, Russell Sage, New York. 
Hernandez, D. and Charney, E.

1998 From Generation to Generation: The Health and Well-Being of Children in Immigrant Families, Committee on the Health and Adjustment of Immigrant Children and Families, Board on Children, Youth, and Families, National Research Council, National Academy Press. Washington, DC.

Hernandez, D.J., and K. Drake

1999 "Socioeconomic and demographic risk factors and resources among children in immigrant and native-born families: 1910, 1960, and 1990", in D.J. Hernandez (Ed.), Children of Immigrants: Health, Adjustment, and Public Assistance, Committee on the Health and Adjustment of Immigrant Children and Families, Board on Children, Youth, and Families, National Academy Press, Washington, DC.

Hernandez, D.

2006 "Analyzing community data" in K.A. Dinan (Ed.), Young Children in Immigrant Families: The Role of Philanthropy, National Center for Children in Poverty, Mailman School of Public Health, Columbia University, New York. www.ncep.org.

Hofferth, Sandra L

1998 "The health status and risk behavior of adolescents in immigrant families", in D.J. Hernandez (Ed.), Children of Immigrants: Health, Adjustment, and Public Assistance, Committee on the Health and Adjustment of Immigrant Children and Families, Board of Children, Youth, and Families, National Academy Press, Washington, DC.

Howes, C., and Aikins, J.

2002 "Peer relationships the transition to adolescence", in R.V. Kail and H.W. Reese (Eds.), Advances in Child Development and Behavior, Academic Press, New York.

Hughes, R.

1987 The Fatal Shore: The Epic of Australia's Founding, Collins Harvill, New York.

Hughes, R.

2000 "Beyond the Fatal Shore," ABC Television (originally an English BBC production), July-August.

Jayasuriya, L., and P. Kee

1999 The Asianisation of Australia? Some Facts and Some Myths, Melbourne University Press, Melbourne.

Jensen, L., and Y. Chitose

1996 "Today's second generation: evidence from the 1990 census", in A. Portes (Ed.), The New Second Generation, Russell Sage Foundation, New York: 82-107.

Jupp, J.

2001 The Australian People: An Encyclopedia of the Nation, Its People and Their Origins, Cambridge University Press, Cambridge, United Kingdom.

Kao, G., and M. Tienda

1995 "Optimism and achievement: the educational performance of immigrant youth”, Social Science Quarterly 76: 1-19. 
Khoo, Siew-Ean

2003 "A greater diversity of origins", in S. Khoo and P. McDonald (Eds.), The Transformation of Australia's Population: 1970-2030, UNSW Press, Sydney: 158-184.

Khoo, S., et al.

2002 Second Generation Australians, Australian Center for Population Research, Canberra, Australia.

King A., et al.

1996 The Health of Youth: A Cross-Sectional Study, World Health Organization. Labov, W

1967 "The effect of social mobility on linguistic behavior", International Journal of American Linguistics 33: 58-75.

Landale, N.S., R.S. Oropesa, and D. Llanes

1998 "Schooling, work, and idleness among Mexican and Non-Latino white adolescents", Social Science Research 27:457-80.

Lieberson, S.

1970 Language and Ethnic Relations in Canada, John Wiley and Sons Inc., New York.

Lieberson, $\mathrm{S}$.

1981 Language Diversity and Language Contact. Stanford University Press, Sanford, California.

Long, J. S.

1997 Regression Models for Categorical and Limited Dependent Variables, Sage Publications, Thousand Oaks, California.

Lopez, D.

1996 "Language: diversity and assimilation", in R. Waldinger and M. Bozorgmehr (Eds.), Ethnic Los Angeles, Russell Sage Foundation, New York: 139-163.

Marshall, M.L., and R.C. Barnett

1993 "Work, family strains, and gains among two-earner couples", Journal of Community Psychology 21: 64-78.

McDonald, P.

2003 "Australia's future population: population policy in a low-fertility society", in S. Khoo and P. McDonald (Eds.), The Transformation of Australia's Population: 1970-2030, UNSW Press, Sydney.

McLanahan, S.

1988 "Family structure and dependency: early transitions to female household headship", Demography 25: 1-16.

McLanahan, S., and G. Sandefur

1994 Growing Up with a Single Parent: What Hurts, What Helps, Harvard University Press, Cambridge, Massachusetts.

Melleuish, G.

1998 The Packaging of Australia: Politics and Culture Wars, University of New South Wales Press, Sydney.

Mendoza, E.S., et al.

1990 "Selected measures of health status for Mexican-American, mainland Puerto Rican, and Cuban-American children", Journal of the American Medical Association 265:227-232. 
Molony, J.

1987 The History of Australia, Viking, Ringwood, Victoria.

Moon, L., P. Meyer, and J. Grau.

1999 Australia's Young People: Their Health and Wellbeing in 1999, AIHW Cat. No. PHE 19, AIHW, Canberra.

Mosler, D.

2002 Australia, The Recreational Society, Praeger, Westport, Connecticut.

National Research Council

1993 "Losing generations: adolescents in high-risk settings" Panel on High Risk Youth, National Research Council, National Academy Press, Washington, DC.

National Research Council and Institute of Medicine

1999a "Risks and opportunities: synthesis of studies on adolescence", Forum on Adolescence. Michele D. Kipke (Ed.), Board on Children, Youth, and Families, National Academy Press, Washington, DC.

1999b "Adolescent development and the biology of puberty summary of a workshop on new research", Forum on Adolescence Michele D. Kipke (Ed.), Board on Children, Youth, and Families, National Academy Press, Washington, DC.

Pawliuk, N., et al.

1996 "Acculturation and psychological functional in children of immigrants", American Journal of Orthopsychiatry 66(1): 111-121.

Perez, L.

1994 "The households of children of immigrants in South Florida: an exploratory study of extended family arrangements", International Migration Review 28 (4): 736-747.

Portes, A., and M. Zhou

1993 "The new second generation: segmented assimilation and its variants", Annals AAPSS 530: 74-96.

Portes, A. (Ed.)

1996. The New Second Generation, Russell Sage Foundation, New York.

Resnick, M.D., et al.

1997 "Protecting adolescents from harm: feelings from the national longitudinal study on adolescent health", Journal of the American Medical Association 278(10): 823-32.

Rumbaut, R. G.

1997 "Ties that bind: immigration and immigrant families in the United States", in A. Booth et al. (Eds.), Immigration and the Family: Research and Policy on

Slee, P. T.

U.S. Immigrants, Lawrence Eribaum Associates, Mahwah, New Jersey3-46.

2002 Child, Adolescent, and Family Development, $2^{\text {nd }}$ Edition, Cambridge University Press, Cambridge.

Social Security Portfolio

1997 "Portfolio budget statements: 1997-98", Budget Related Paper No. 1.14, Australian Government Printing Office, Canberra. 
Sorenson, S.B., and H. Shen

1996 "Youth suicide trends in California: an examination of immigrant and ethnic group risk", Suicide and Life-Threatening Behavior 26(2): 143-154.

Statistics New Zealand

1999 New Zealand Now: Children Statistics, Wellington, New Zealand.

Suarez-Orozco, C., and M. Suarez-Orozco

2001 Children of Immigration, Harvard University Press, Cambridge.

Thornton, A., and D. Camburn

1987 "The influences of the family on premarital sexual attitudes and behavior", Demography 24: 323-40.

Waterhouse, R.

1995 Private Pleasures, Public Leisure: A History of Australian Popular Culture Since 1788, Longman Australia, Melbourne.

Waters, M.

1997 "Immigrant families at risk: factors that undermine chances for success", in A. Booth et al. (Eds.), Immigration and the Family: Research and Policy on U.S. Immigrants, Lawrence Eribaum Associates, Mahwah, New Jersey: 79-90.

Waters, M. C.

1996 "Ethnic and racial identities of second generation black immigrants in New York City", in A. Portes (Ed.), The New Second Generation, Russell Sage Foundation, New York: 171-196.

Watson, N. and Wooden, M.

2002 "The household, income, and labour dynamics in Australia (HILDA) survey: wave 1 survey methodology", HILDA Project Technical Paper Series No. 1 /02, Melbourne Institute of Applied Economic and Social Research, University of Melbourne.

Wildermuth, N.L.

1990 "Loneliness in adolescence: why it occurs and what to do about it", in P.C.L. Heaven and V.J. Callan (Eds.), Adolescence: An Australian Perspective, Harcourt Brace Javonvich, Sydney: 255-270.

Wooden, M., S. Freidin and N. Watson

2002 "The household, income and labour dynamics in Australia (HILDA) survey: wave 1", Australian Economic Review, 35: 339-348.

World Health Organization

1998 Guidelines for Controlling and Monitoring the Tobacco Epidemic, World Health Organization, Geneva.

Zhou, M.

1997 "Growing up American: the challenge confronting immigrant children and children of immigrants", Annual Review of Sociology 23: 63-95.

Zhou, M., and C. L. Bankston III

1996 "Ethnic and racial identities of second generation black immigrants in New York City", in A. Portes (Ed.), The New Second Generation, Russell Sage Foundation, New York: 171-196. 


\section{LES COMPORTEMENTS SANITAIRES À RISQUE DES ADOLESCENTS NÉS DANS DES FAMILLES IMMIGRÉES ET LEUR CONNEXITÉ SOCIALE : LE CAS DE L'AUSTRALIE}

L'auteur compare des données sur les comportements sanitaires et la connexité sociale des adolescents issus de familles immigrées en Australie avec ceux des adolescents de familles non immigrées. Le résultat est que, par rapport aux adolescents de la première et de la deuxième génération, ceux de la troisième génération sont plus enclins à consommer de l'alcool, mais bénéficient davantage d'un soutien social, ont une activité physique accrue et sont plus souvent affiliés à un club ou à un groupe. Les adolescents de la troisième génération fument moins que ceux de la deuxième génération. Bien qu'apparemment protégés contre d'éventuels dangers, les adolescents immigrés ne tirent pas parti des traditions culturelles australiennes en matière d'activité physique et de participation sociale. Cependant, au fil des générations, la participation sociale et l'activité physique augmentent. Enfin, plus la durée passée en Australie s'allonge, plus les effets protecteurs de la famille immigrée contre certains dangers s'amenuisent. En résumé, le processus d'assimilation conduit les adolescents des familles immigrées à adopter les coutumes sociales australiennes dominantes en matière de comportements sanitaires et sociaux. 


\section{COMPORTAMIENTOS ARRIESGADOS DE SALUD Y RELACIÓN SOCIAL DE LOS ADOLESCENTES DE FAMILIAS DE INMIGRANTES: PRUEBAS PROVENIENTES DE AUSTRALIA}

Utilizando datos obtenidos en Australia, se ha efectuado una comparación de los resultados relativos al comportamiento sanitario y a la relación social de los adolescentes de familias inmigrantes con los resultados de adolescentes de familias no inmigrantes. Se llega a la conclusión de que la primera y segunda generación de adolescentes tiene menos probabilidades de consumir alcohol y carecen de apoyo social en comparación a la tercera generación de adolescentes, pero tienden a ser menos activos físicamente y a no pertenecer a un club o grupo social que la tercera generación de adolescentes. La segunda generación de adolescentes tiene mayor tendencia a fumar que la tercera generación de adolescentes. Los resultados apuntan a que los inmigrantes adolescentes parecen estar protegidos de riesgos negativos, pero al mismo tiempo, no se benefician de las tradiciones culturales de Australia en materia de actividades físicas y adaptación social. Ahora bien, a través de las generaciones, se vislumbra una mayor participación social y actividad física. Por último, a medida que aumenta el tiempo de permanencia en Australia, el efecto protector de la familia inmigrante contra ciertos riesgos negativos se va desvaneciendo. Globalmente, el proceso de asimilación conduce a los adolescentes de familias de inmigrantes a adoptar las costumbres sociales prevalecientes en Australia en materia sanitaria y social. 


\section{APPENDIX A: BACKGROUND ON AUSTRALIA'S DIVERSITY OF IMMIGRANTS}

Over the last three decades of the 20th century, immigrants to Australia have progressively become younger and much more likely to come from the AsiaPacific region (ABS 2000a, 2000b). Specifically, over those decades immigration from European countries to Australia, especially the United Kingdom and Ireland, decreased markedly while immigration from the geographically closer countries of the Asia-Pacific region increased significantly (Jayasuriya and Kee, 1999; Jupp, 2001; Burnley, 2001).

Predictably, therefore, the cultural mix of people migrating to Australia has greatly diversified. During the 1950s and 1960s, the high proportion of immigrants from Europe reflected the role Australia played in resettling people displaced by World War II. At the end of the 1960s, the growing proportion of immigrants born in the United Kingdom and Ireland was accompanied by substantial migration from southern Europe, for example, Greece, Italy, and Croatia. Then, during the late 1970s and 1980s, immigrants became increasingly likely to have been born in countries of the Asia-Pacific region, for example, the Philippines, New Zealand, Cambodia, and Viet Nam (ABS 2001b).

Thus, many years of immigration from a wide range of countries has made Australian society culturally diverse. Illustrating the breadth of diversity, the 1996 Census showed that Australians had been born in more than 200 countries. In 2000 , there were an estimated 4.5 million overseas-born residents, constituting almost one-quarter $(24 \%)$ of the population. More than half of these $(53 \%)$ had been born in Europe or the former USSR. Nearly one in four (24\%) had been born in Asian regions, with greatest representation from Viet Nam, China, the Philippines and India. Smaller proportions had been born in Oceania and Antarctica, Africa and the Middle East and the Americas (ABS 2001b). Table A.1 below displays the major countries from which individuals have emigrated over the last 50 years. 


\begin{tabular}{|c|c|c|c|c|c|c|}
\hline Countries of origin ${ }^{a}$ & $\begin{array}{c}1949-50 \\
\%\end{array}$ & $\begin{array}{c}1959-60 \\
\%\end{array}$ & $\begin{array}{c}1969-70 \\
\%\end{array}$ & $\begin{array}{c}1979-80 \\
\%\end{array}$ & $\begin{array}{c}1989-90 \\
\%\end{array}$ & $\begin{array}{c}1999-00 \\
\%\end{array}$ \\
\hline New Zealand & 1.9 & 1.3 & 2.7 & 16.3 & 9.2 & 23.7 \\
\hline United Kingdom / Ireland & 28.2 & 36.1 & 41.6 & 21.5 & 21.1 & 10.8 \\
\hline China & 0.8 & 0.4 & 0.2 & 1.6 & 2.5 & 7.4 \\
\hline South Africa & 0.3 & 0.4 & 0.5 & 3.4 & 2.0 & 6.2 \\
\hline India & 0.7 & 0.4 & 2.1 & 1.0 & 2.5 & 5.0 \\
\hline Former Yugoslavia & 0.8 & 6.0 & 14.2 & 2.1 & 1.6 & 4.6 \\
\hline Philippines & n.a. & n.a. & 0.1 & 2.5 & 5.0 & 3.5 \\
\hline Malaysia & 0.4 & 0.2 & 0.5 & 2.0 & 5.3 & 1.9 \\
\hline Viet Nam & n.a. & n.a. & n.a. & 16.0 & 9.2 & 1.6 \\
\hline Hong Kong & 0.3 & 0.0 & 0.2 & 1.0 & 6.6 & 1.6 \\
\hline Germany & 34.6 & 9.0 & 2.2 & 1.5 & 0.9 & 0.8 \\
\hline Netherlands & 1.7 & 8.9 & 1.5 & 1.5 & 0.4 & 0.5 \\
\hline Poland & 3.0 & 1.8 & 0.3 & 1.7 & 1.4 & 0.2 \\
\hline Italy & 9.3 & 15.4 & 5.6 & 1.3 & 0.3 & 0.2 \\
\hline Austria & 3.7 & 1.9 & 0.5 & 0.3 & 0.2 & 0.1 \\
\hline Greece & 1.1 & 5.9 & 5.9 & 1.1 & 0.3 & 0.1 \\
\hline Other & 13.3 & 12.2 & 21.9 & 25.4 & 31.5 & 31.7 \\
\hline Total ${ }^{\mathrm{b}}$ & 100.0 & 100.0 & 100.0 & 100.0 & 100.0 & 100.0 \\
\hline \multicolumn{7}{|c|}{ 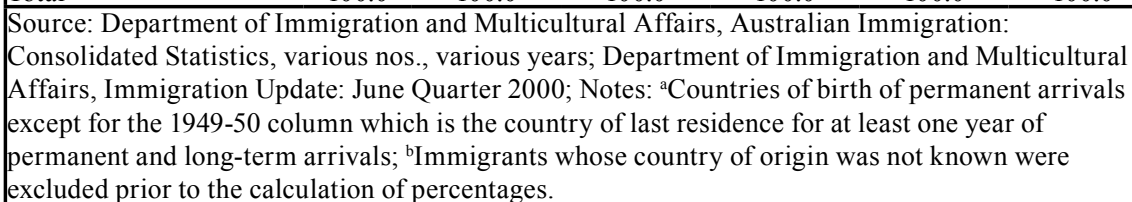 } \\
\hline
\end{tabular}

